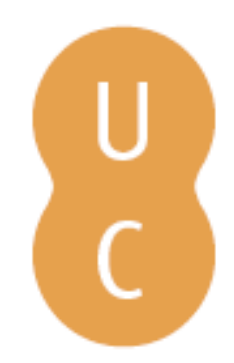

\title{
pommalina
}

\section{Temporal changes to fire risk in Disparate WUI communities in Southern California, USA}

Autor(es): $\quad$ Dicus, Christopher A.; Leyshon, Nicola C.; Sapsis, David B.

Publicado por: Imprensa da Universidade de Coimbra

URL

persistente: URI:http://hdl.handle.net/10316.2/34284

DOI: $\quad$ DOI:http://dx.doi.org/10.14195/978-989-26-0884-6_105

Accessed : $\quad$ 26-Apr-2023 12:38:18

A navegação consulta e descarregamento dos títulos inseridos nas Bibliotecas Digitais UC Digitalis, UC Pombalina e UC Impactum, pressupõem a aceitação plena e sem reservas dos Termos e Condições de Uso destas Bibliotecas Digitais, disponíveis em https://digitalis.uc.pt/pt-pt/termos.

Conforme exposto nos referidos Termos e Condições de Uso, o descarregamento de títulos de acesso restrito requer uma licença válida de autorização devendo o utilizador aceder ao(s) documento(s) a partir de um endereço de IP da instituição detentora da supramencionada licença.

Ao utilizador é apenas permitido o descarregamento para uso pessoal, pelo que o emprego do(s) título(s) descarregado(s) para outro fim, designadamente comercial, carece de autorização do respetivo autor ou editor da obra.

Na medida em que todas as obras da UC Digitalis se encontram protegidas pelo Código do Direito de Autor e Direitos Conexos e demais legislação aplicável, toda a cópia, parcial ou total, deste documento, nos casos em que é legalmente admitida, deverá conter ou fazer-se acompanhar por este aviso.

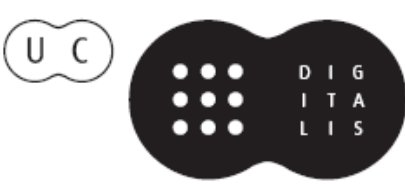




\section{ADVANCES IN}

Forest Fire

\section{RESEARCH}

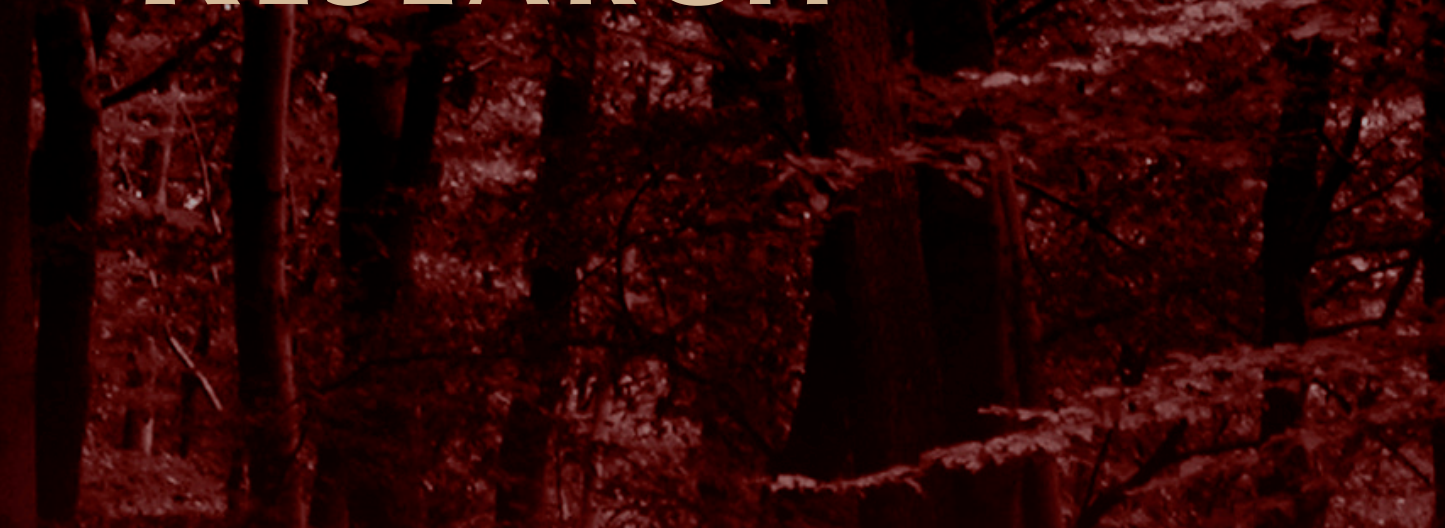

\section{DOMINGOS XAVIER VIEGAS}

\section{EDITOR}




\title{
Temporal changes to fire risk in Disparate WUI communities in Southern California, USA
}

\author{
Christopher A. Dicus ${ }^{a}$, Nicola C. Leyshon ${ }^{b}$, David B. Sapsis ${ }^{c}$ \\ ${ }^{a}$ California Polytechnic State University, Natural Resources Management \& Environmental \\ Sciences Department, San Luis Obispo, CA 93402,USA; cdicus@calpoly.edu \\ ${ }^{b}$ California Polytechnic State University San Luis Obispo, Natural Resources Management \& \\ Environmental Sciences Department, San Luis Obispo, CA 93402, USA; nleyshon@ calpoly.edu \\ ${ }^{c}$ California Department of Forestry \& Fire Protection, PO Box 944246, Sacramento, CA 94244, \\ USA; dave.sapsis@fire.ca.gov
}

\begin{abstract}
To aid policy development that reduces fire losses in the wildland-urban interface, we are evaluating changes to risk through time in dissimilar communities that are expanding into fire-prone areas of southern California, USA. Conventional wisdom states that escalating losses are caused, in part, by an expansion of residential development into fire-prone areas. However, various mitigation strategies such as defensible space and improved construction standards have recently been mandated for new developments in California so as to reduce the risk of these losses. Subsequently, older high-risk communities may actually become buffered from wildfires as the WUI expands and subsequently lessens their exposure to flames and embers. Thus, expanding WUI may either increase or decrease risk of residential loss dependent upon the extent of altered fire exposure and the application of mandated mitigation strategies.

To help elucidate this seeming dichotomy, we are utilizing various GIS strategies to spatially analyze changes to development and subsequent risk of structural ignitions through time in three expanding, but demographically dissimilar, residential communities in southern California. Here, we quantify temporal changes in the area exposed to fire hazards in each of the communities over a 26-year period. The amount of area exposed to wildfire increased in each of the communities. The degree and location of newly exposed development, however, differed between communities, which may influence fire risk in an impending assessment we will conduct as part of a larger research project of the area.
\end{abstract}

Keywords: Wildland Urban Interface, Land Use, Urban Expansion, Wildfire, Risk, Urban Resiliency, San Diego County

\section{Introduction}

Even with increasing proportions of governmental budgets allocated to fire suppression resources, wildfires annually destroy great numbers of homes and critical infrastructure in the wildland-urban interface (WUI). Indeed, since 2002 in the US, the largest fires in the histories of California, Arizona, Colorado, New Mexico, Utah, Oregon, and Texas have occurred in spite of increased fire agency staffing, equipment, and training (National Interagency Fire Center 2014). In California alone, thirteen fires over 40,500 ha in size have burned since 1990, with 7 of the 10 most destructive wildfires having occurred during this period, resulting in the loss of 53 lives and almost 12,000 structures (California Department of Forestry \& Fire Protection 2013). To aid policy development that reduces these losses, we are evaluating how risk changes through time in communities that are expanding into fire-prone areas, but which vary in demographics and socioeconomic status.

The cause of increased fire losses in the WUI is related to a myriad of complex and interacting factors, the influence of each which varies by time and by place. Of especial concern, burgeoning population growth into fire-prone areas has resulted in greater exposure of residential development to wildland fire. Further, with increased population growth into the WUI, there are increased ignitions through accident or arson (Syphard et al. 2008). 
To better facilitate sustainable communities in the WUI, managers need an accurate and detailed assessment of not only the fire hazard in a given area, but also its risk to assets of value. Many methods of WUI risk assessment involve the use of maps or spatial data (Bar Massada et al., 2009; Prestemon et al. 2002). Mapping and defining the WUI is critical for wildfire risk management because as the WUI expands, it must be monitored in order for planners to make effective policy decisions to mitigate risk (Stewart et al. 2007). Such maps provide powerful visual images and are commonly used as tools to direct policy, which has contributed to their increasing use in the US (Radeloff et al.2005; Theobald and Romme 2007). Many studies of WUI fire risk have used Geographic Information Systems (GIS) to examine changes through time (Greenberg et al. 1997; Jain et al., 1996; Nourbakhsh et al. 2006), which is an effective approach because fire risk analysis commonly employs both spatial and temporal attributes (Chuvieco et al. 2010). A GIS-based model is an especially effective approach for areas in which a large part of the land is being encroached upon by development (Jaiswal et al. 2002).

Conventional wisdom is that escalating WUI losses are caused, in part, by an expansion of residential development into fire-prone areas. However, if new construction and landscaping adheres to strict mitigation strategies, then expansion of the WUI (with higher-resistant development) may actually buffer the older, high-risk communities from exposure to flames and embers. Thus, expanding WUI may either increase or decrease risk of residential loss dependent upon the extent of adhering to mandated mitigation strategies.

To help elucidate this seeming dichotomy, we are utilizing various GIS and remote sensing strategies to spatially analyze changes to urban expansion and subsequent potential risk of structural ignitions (including differing wildfire exposure via roofing materials, defensible space, and housing density) through time in growing, fire prone communities in southern California. While these communities are geographically nearby, they are demographically dissimilar, which may influence the ability to mitigate risk. The work presented here is the first stage of a larger, multi-phase project that is investigating changes in fire risk in those communities and the overriding causative agents influencing any changes to risk.

\section{Methods}

\subsection{Study Site}

Three residential communities in San Diego County, California, USA were assessed including Rancho Santa Fe, Ramona, and Julian (Figure 1). All of the communities have conditions conducive to high fire hazard, including a Mediterranean climate with extended drought, regular occurrence of highvelocity foehn winds (commonly referred to as Santa Ana winds), steep terrain, and flammable vegetation, all of which have led to several high-intensity, high-loss wildfires there in the past 10 years. The three specific communities represent a range of rates of development, demographics, housing density and geographic area deemed WUI. 


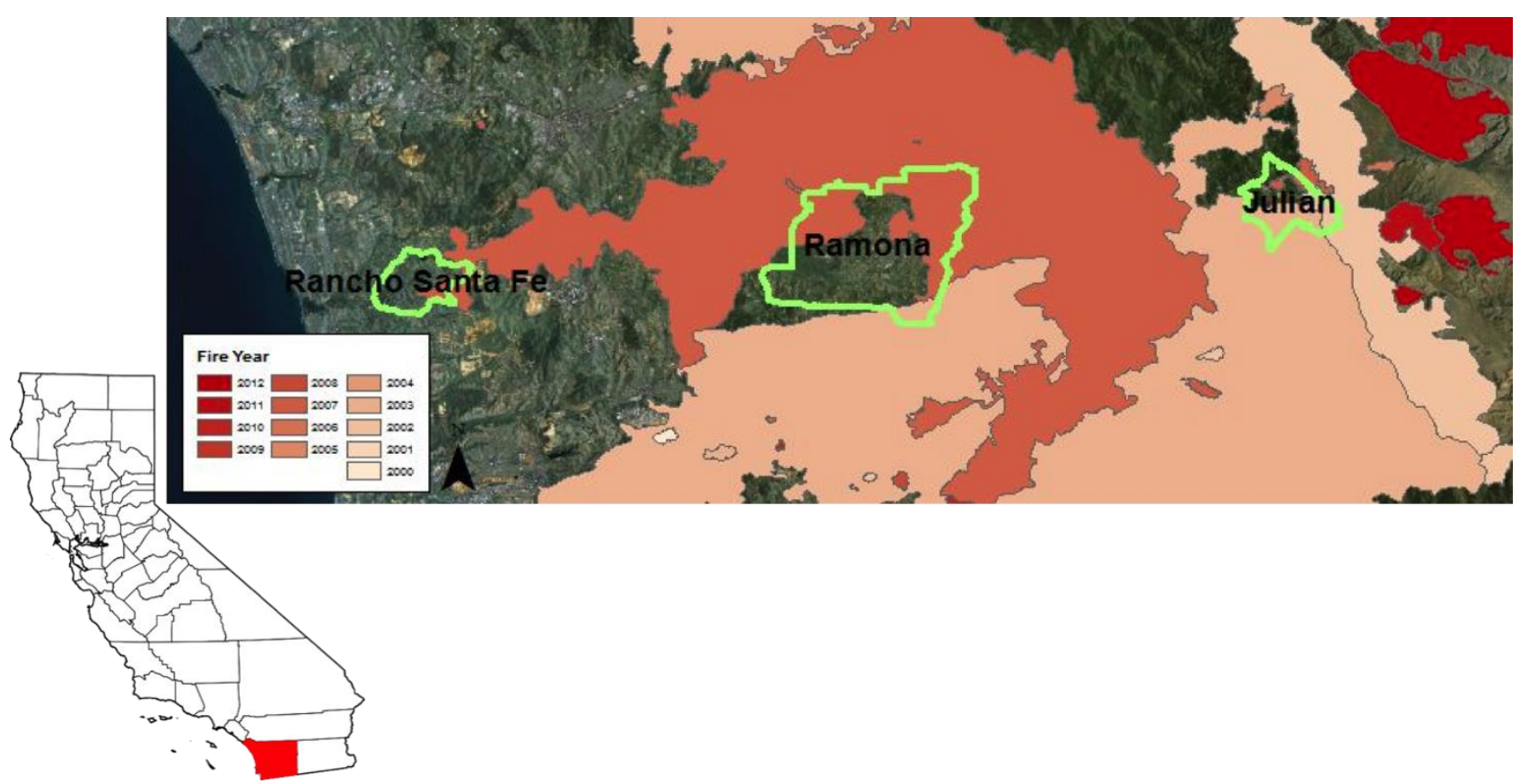

Figure 1. Location of study sites and map of 12-year fire history around study sites (Top Left)

Specific demographics of each of the three communities are detailed in Table 1. Rancho Santa Fe has a population of 3,100 with an average household income of over $\$ 200,000$. The community has taken numerous additional measures above county and state regulations to mitigate fire hazard and lower the likelihood of structural ignitions during wildfires. Some of these measures include mandatory installation of residential fire sprinklers, fire-resistant landscaping, setbacks, and widening of roadways (District 2004). Rancho Santa Fe is regularly viewed as a leader in the US in terms of mitigating fire risks.

While geographically near Rancho Santa Fe, Ramona and Julian differ in demographics, including population size and annual household income. A recent wildfire hazard risk assessment (Botts et al. 2013) found that Ramona and Julian had the most residential properties at risk in San Diego County. Both communities have significantly lower mean household incomes and subsequent ability to mitigate against wildfire) than Rancho Santa Fe. Ramona is over six times larger than Rancho Santa Fe. Conversely, Julian has half the population of Rancho Santa Fe.

Table 1. Demographics of the three assessed communities.

\begin{tabular}{lcccc} 
Study Site & Population & $\begin{array}{c}\text { Average Income } \\
\text { (USD) }\end{array}$ & $\begin{array}{c}\text { Average House Value } \\
\text { (USD) }\end{array}$ & WUI type \\
\hline Rancho Santa Fe & 3117 & $\$ 180,612$ & $\$ 1,139,911$ & Interface \\
Ramona & 20,292 & $\$ 60,033$ & $\$ 485,597$ & Interface \\
Julian & 1,502 & $\$ 65,781$ & $\$ 510,138$ & Intermix
\end{tabular}

\subsection{Data Analysis}

In order to determine land use changes from non-urban to urban through time, we utilized publicly available land use data from the San Diego Regional Data Warehouse (SanGIS 2014). Land use data were available for pre-1986, 1990, 1995, 2000, 2004, 2008 and 2012. The data contained many classes of land use; for the purpose of this study, each year of land use data was classified as either urban or 
non-urban. Agricultural and landscaping uses (e.g., vineyards and parks) were considered non-urban. All land uses involving clearing of vegetation and/or paving (e.g., telecommunication right-of-way) were considered urban.

The years of land use were then layered chronologically to show development over time (Figure 2). To quantify the changes in land use over time, the area of the polygons were clipped to a defined study area. In order to be inclusive of all structures within the WUI, a $3.2 \mathrm{~km}$ buffer was created around each of the US census-designated place (CDP) boundaries of the study sites, the size of which was chosen because embers regularly travel $1.6 \mathrm{~km}$ (i.e., half the buffer size) or more during extreme weather conditions. Also, we included any structures that resided within the $3.2 \mathrm{~km}$ buffer from the CDP boundary. Given the nature of urban expansion, it is intuitive to include structures on the outskirts of current boundaries, as the developments of the future are likely to be located here. The land-use data was then clipped to each buffer zone, and the area for each polygon was calculated using GIS. Evaluation included percentage change in urban land use.

\section{Results}

Figure 2 shows the results of the land use mapping over time. Rancho Santa Fe has clustered recent development in the eastern portion of the community, which was expected because other existing communities on the western portion limit development there. As can be seen in Figure 1, wildfire events have historically approached Rancho Santa Fe from the east, which is due to the general direction of Santa Ana winds. The newer developments (purple and pink polygons) therefore have the potential to act as a buffer for the town if developed with more fire-resistant construction and landscaping is maintained.

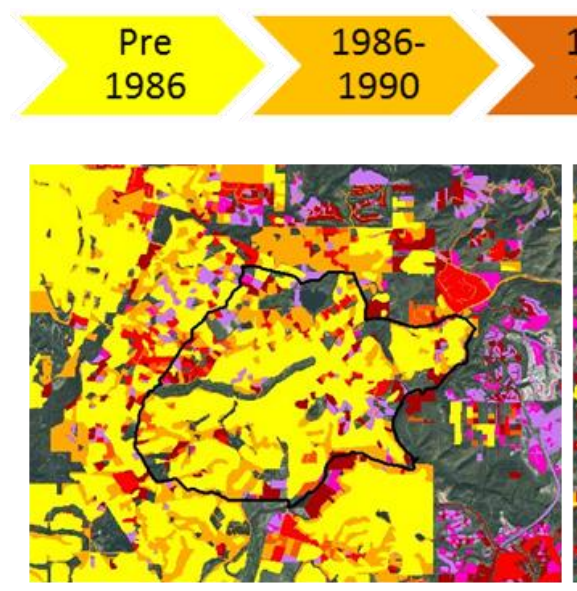

(A)

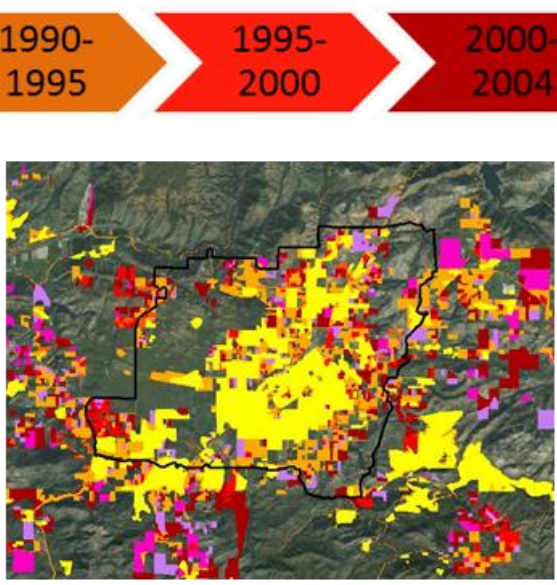

(B)

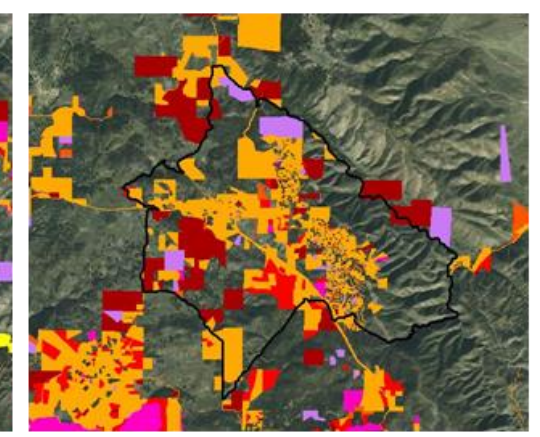

(C)

Figure 2. Change in designated land use from "non-urban" to "urban" over time in Rancho Santa Fe (A), Ramona (B), and Julian (C). Data per SanGIS (2014)

Much of the new development in Ramona has taken place on the outskirts of the town to the northeast and southwest, which might be result of the topography of the area limiting new development to those areas. The 2007 Witch Creek burned through the northeast portion of Ramona.

Land use data was not available for Julian pre-1986. The community has experienced little development in the past 8 years. Although the polygons depicting new development in Julian may appear large compared to Rancho Santa Fe and Ramona (Figure 2), many of these polygons only contain 1-3 structures within them. Julian differs from the former two communities that form a classic interface between the built and natural environments. Instead, Julian represents a classic intermix WUI community, where many structures are isolated from each other and have larger areas of vegetative 
fuels between them. This is especially the case near the borders of the community. This differs greatly from Rancho Santa Fe, where there is a higher density of structures in both the new and old developments.

Figure 3 illustrates the change in urban land use over time in each of the communities. Each community demonstrated an upward trend over the 26-year period in the percentage of total lands deemed urban development. Results indicate that the majority of urban development in all three of the study sites is taking place as a result of expanding WUI (vs. residential infill into the existing communities). Rancho Santa Fe had the greatest rates of development of the three study sites.

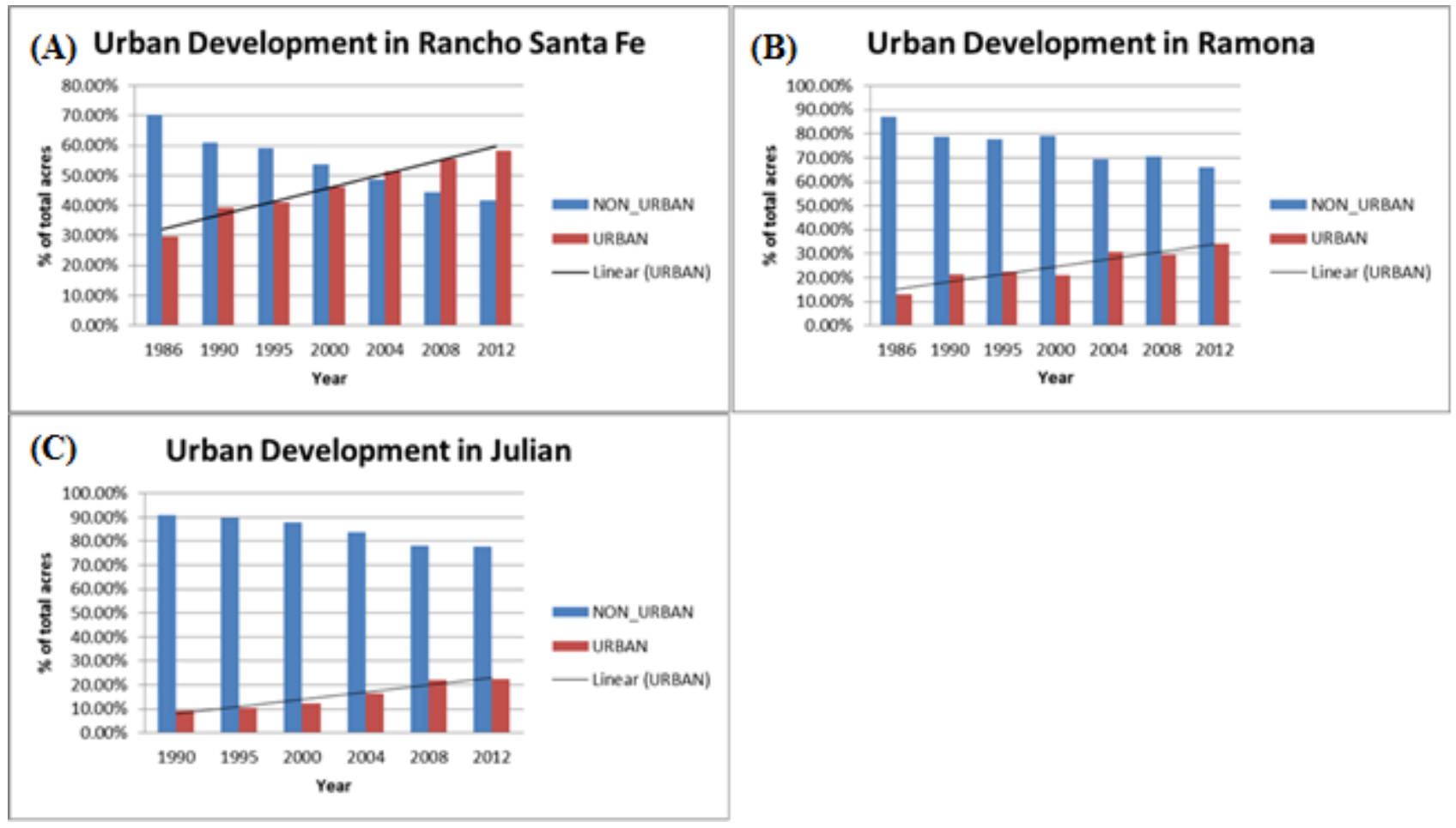

Figure 3. Proportional changes over time of urban and non-urban land uses in Rancho Santa Fe (A), Ramona (B), and Julian (C), including $3.2 \mathrm{~km}$ buffer outside of CDP boundaries). (SanGIS 2014)

\section{Discussion}

The results confirm that all three communities experienced expansion of the WUI over the past 26 years. Despite major wildfires in San Diego County in 2003 and 2007, which destroyed thousands of buildings, structures continue to be built in fire-prone areas, both to replace existing homes destroyed during wildfires and because of increasing populations in these communities. As previously noted, however, this new development could either exacerbate an already tenuous situation or could provide a means to reduce fire risk to older building interior to the new development, dependent on the nature and degree of fire mitigations that are employed.

Figure 4 illustrates how newer communities could potentially buffer the older communities if appropriate mitigation measures are employed in the new developments. In Rancho Santa (Figure 4A), the parcels east of the yellow line were developed 2004-2010 and could potentially provide a buffer to the structures built 1986, which are west of the yellow line. Likewise, in Julian (Figure 4B), the purple polygon contains a parcel developed in the 2004-2008 time frame (represented by the purple line) could buffer the structure built pre-1990 (the parcel of which is represented by the orange line). 


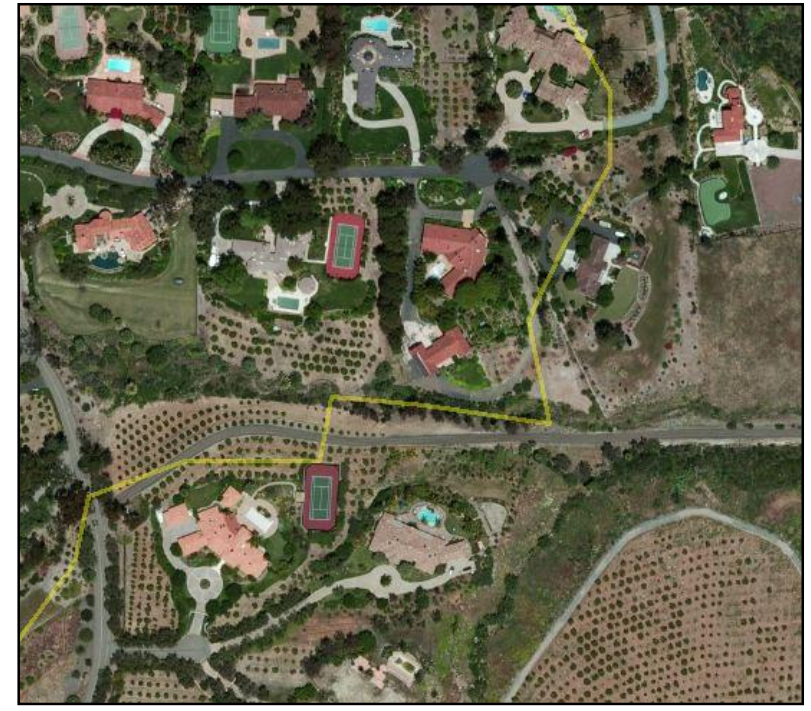

(A)

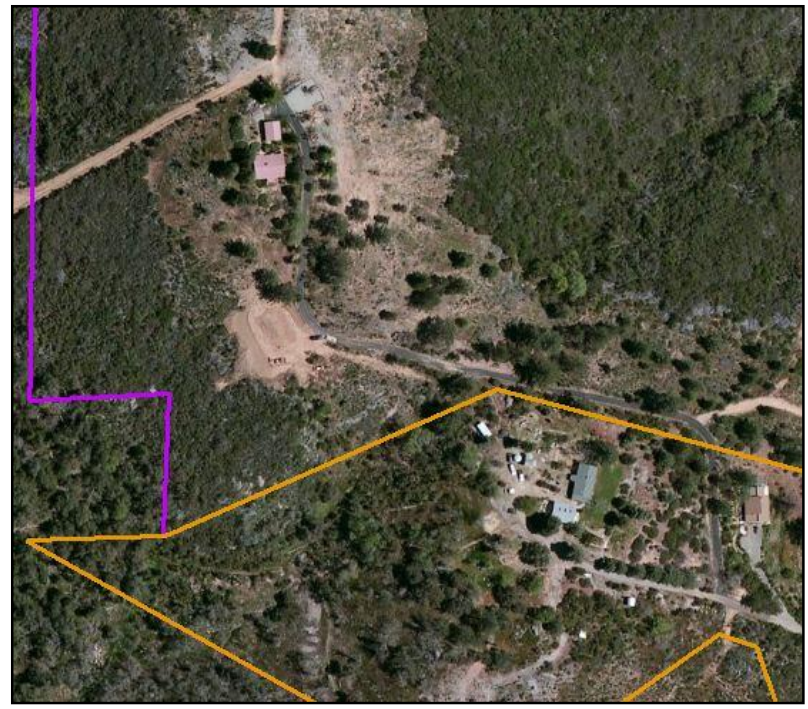

(B)

Figure 4. Examples of how new developments (with stricter construction and landscaping standards) could buffer older developments in Rancho Santa Fe (A) and in Julian (B).

Fire managers have multiple mitigation strategies to reduce the risk of fire loss in the WUI at their disposal. One mitigation activity is management of vegetative fuels. There is considerable evidence that fire intensity (and subsequent loss) is reduced when a fire advances through vegetation that has recently been treated by prescribed fire or by mechanical means (Martinson and Omi 2003, Skinner et al. 2004, Finney et al. 2005). Thus, there has been an escalating call by both land management agencies and the public to significantly modify the amount and arrangement of vegetation in wildlands near the communities so as to mitigate the potential negative impacts of high-severity fires (Dombeck et al. 2004; Abrams and Lowe 2005; Ostergren et al. 2008). Indeed, the 2001 National Fire Plan, the 2003 Healthy Forest Restoration Act, and the 2014 National Cohesive Wildland Fire Management Strategy all prioritized fuel treatments into national fire policy in the US.

That said, many argue that treating vegetation outside the area immediately surrounding a structure (commonly referred to in the US as the "Home Ignition Zone") is largely futile because of its minimal impact on the factors that impact structural ignition (Cohen 2000). Creation of a defensible space immediately surrounding a building would reduce structural ignitions via direct flame impingement or radiant heat transfer (Cohen and Butler 1998). To that end, the California Public Resources Code Section 4291 has required $9.15 \mathrm{~m}$ of defensible space around structures since 1991, which was increased to $30.48 \mathrm{~m}$ in 2006.

Even if current regulations are enforced, it must be noted that defensible space would not impact structural ignition from lofted embers, which is a more critical factor in residential losses than flame impingement or radiant heat (Cohen 2000). To mitigate potential residential losses, in 2008 California enacted building standards for new construction in areas in which the state has primary fire protection responsibility. California Code of Regulations Title 24, Part 2, Section 701.A now requires standards for some portions of dwellings that are most prone to ignition, including roofs, siding, attic ventilation, windows, decks, and others. While the new standards will likely reduce fire losses in future development, they obviously cannot impact vulnerability of existing structures.

Additionally, there has been a greater call to limit new construction into areas in which topography, such as steep slopes, naturally facilitates active fire spread (Syphard et al. 2008). Indeed, some areas in California now require a minimum setback of structures away from slopes so as to limit their exposure to convective heat transfer from burning vegetation. Of interest, some high-value communities (e.g., Rancho Santa Fe in this study) have taken novel approaches to meet setback regulations such as constructing enormous retaining walls (costing in excess of \$400,000 USD) on the 
sides of slopes in order to artificially meet the setback standards there (Mike Scott, Rancho Santa Fe Fire District, personal communication).

Unfortunately, W U I residents seem to frequently resist the very regulations that were developed to protect them and their property. For example, residents of one fire-prone area in California did not adhere to defensible space standards because of privacy concerns and a desire to be immersed in "natural" conditions (Delfino and Dicus 2007). Further, fire agencies commonly do not enforce the state-mandated defensible space regulations due to reasons such as lack of budget and personnel or unwillingness to play a perceived adversarial role with the public that they serve. Thus, adherence to sound mitigation standards varies by place and depends in part on the fiscal ability of residents to implement these strategies and the willingness of fire agencies to enforce existing regulations.

The buffer zones identified in this portion of the study, which demonstrate changes to urban expansion through time, will be used for future analysis to assess changing fire risk over time to these communities. In addition to the more traditional parameters of housing density, vegetation, and fire probability, there is a great need to develop a WUI risk assessment that more fully considers aspects of individual structure ignition (Calkin et al. 2014; Chuvieco et al. 2010; Menakis et al. 2003). For example, the inclusion of near-structure vegetation and defensible space in a remote sensing analysis would provide a better means of quantifying fire risk in WUI communities (Calkin et al. 2014; Menakis et al. 2003). Further, knowledge of a structure's location and arrangement relative to other structures or flammable materials is critical in effective risk analysis (Cohen, 2000; Murnane, 2006). Unfortunately, many risk analysis studies have not considered the fine-scale characteristics of vegetation immediately surrounding a home or have assumed that all structures are equally flammable (Bar Massada et al. 2009; Menakis et al. 2003; Prestemon et al. 2002).

Risk analysis has also traditionally emphasized the ignition and propagation potential of a wildfire, rather than it potential damages (Chuvieco et al. 2010). The idea of vulnerability is an important new addition to fire risk assessment models (Calkin et al. 2010; Chuvieco et al. 2012), which is a result of multiple high-loss wildfire events in the US in recent years (Calkin et al. 2014).

Sound risk analysis must therefore include elements of both fire hazard and the susceptibility of assets of value (Calkin et al. 2010). Thus, in subsequent phases of this on-going work, we will employ a WUI risk assessment protocol that more fully considers aspects of individual structural ignition as well as surrounding fire hazard and community variables such as housing density and proximity to fuels (Menakis et al. 2003; Chuvieco et al. 2010; Calkin et al. 2014). In order to have an accurate assessment of risk, we will consider roofing materials, vegetation proximity, structure density, eaves, windows, decking and siding materials. We will also measure compliance with defensible space legislation and general homeowner maintenance within the home ignition zone (Figure 5). All of these factors are critical in measuring structural vulnerability as defensible space may not impact structural ignition from lofted embers, which is a more critical factor in residential losses than flame impingement or radiant heat (Cohen 2000; Quarles et al. 2010). 


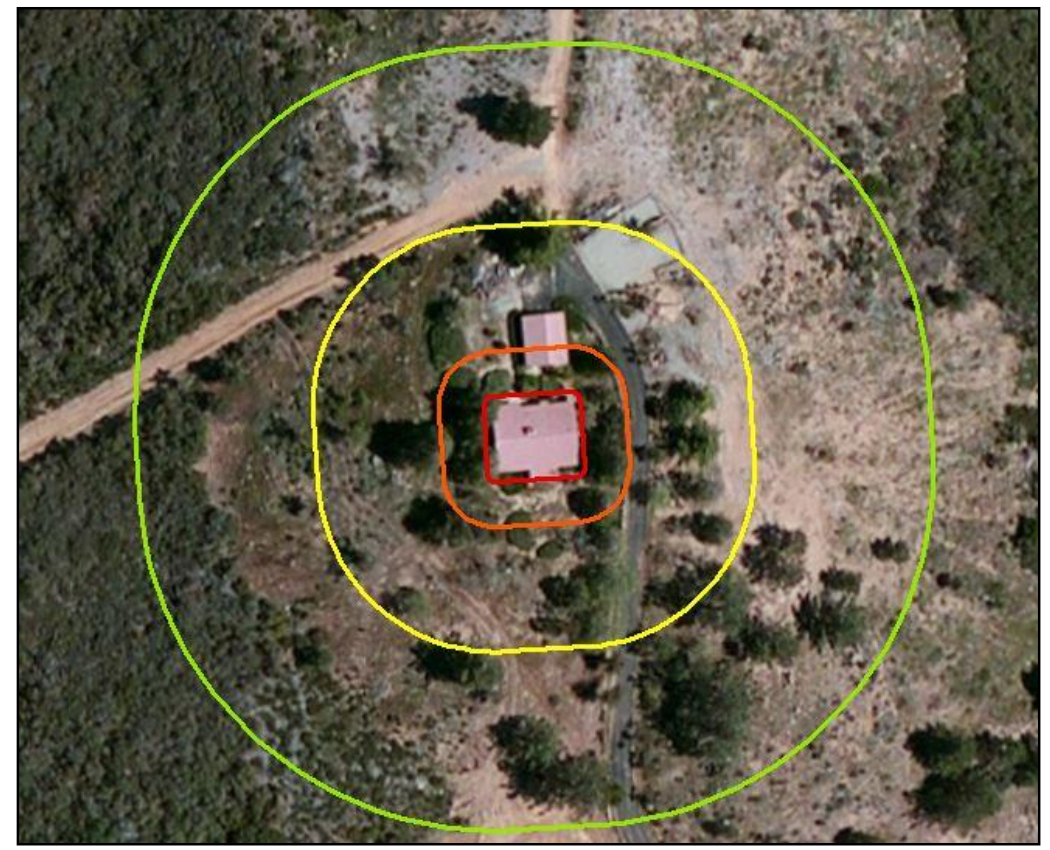

Figure 5. Management of the home ignition zone must include implementation of defensible space at multiple scales, the most important of which is the $30 \mathrm{~m}$ immediately surrounding a structure.

\section{Conclusions}

As new buildings and infrastructure are developed into fire-prone WUI areas, measures must be taken to prevent losses from wildfire. Strategic placement of new developments to buffer vulnerable communities could provide multiple benefits the community. It is significantly more cost-efficient to build a community in a fire resistant manner at the onset than it is to retrofit an existing community. Our on-going research, of which this manuscript details the initial stages, will investigate if and how fire risk is being changed through time in these communities, which while geographically close vary significantly in community demographics and in socioeconomic status. We expect that there will be differences between the three communities in the implementation of mitigation strategies (and subsequent risk of loss) based upon the disparate abilities of residents to pay for modifications and jurisdictional differences in enforcement of the existing regulations.

To sustainably manage the WUI, stakeholders from diverse disciplines and worldviews must collaborate to reduce fire risk in a manner that is environmentally sound (Dicus and Scott 2006). Our ongoing research will provide land managers and policymakers with a means to facilitate that endeavor, creating a process that fosters meaningful dialogue between individuals and groups that sometimes have conflicting objectives. Indeed, while our research is regional in nature, it is hoped that the process that we develop will be able to be utilized by scientists, land managers, and policymakers on an international scale.

\section{Acknowledgements}

Funding for this work was provided by the California Department of Forestry \& Fire Protection, the California State University Agricultural Research Initiative, and the McIntire-Stennis Cooperative Forestry Research Program. We are grateful to ongoing advice and insight provided by Dan Turner (Cal Fire, retired), Kate Dargan (Intterra), and Steve Quarles (Insurance Institute for Business \& Home Safety). 


\section{References}

Abrams, J., and K. Lowe (2005) Public perceptions of forest restoration in the southwest: A synthesis of selected surveys and literature. Ecological Restoration Institute. Northern Arizona University, Flagstaff, Arizona, USA.

Bar Massada, A., V.C. Radeloff, S.I. Stewart, T.J. Hawbaker (2009) Wildfire risk in the wildlandurban interface: a simulation study in northwestern Wisconsin. Forest Ecology and Management 258:1990-1999.

Botts, H., T. Jeffery, K. Stephen, S. Mcabe, B. Stueck, L. Suhr (2013) Wildfire Hazard Risk Report, Corelogic.

California Department of Forestry \& Fire Protection (2013) 20 Largest California Wildland Fires (By Structures Destroyed). Available

at http://interwork.sdsu.edu/fire/resources/documents/20LSTRUCTURES.pdf , <2-14-14>.

Calkin, D.E., J.D. Cohen, M.A. Finney, M.P. Thompson (2014) How risk management can prevent future wildfire disasters in the wildland-urban interface. Proceedings of the National Academy of Sciences 111:746-751.

Chuvieco, E., I. Aguado, S. Jurdao, M. Pettinari, M. Yebra, J. Salas, S. Hantson, J. de la Riva, et al. (2012) Integrating geospatial information into fire risk assessment. International Journal of Wildland Fire.

Chuvieco, E., I. Aguado, M. Yebra, H. Nieto, J. Salas, M.P. Martín, L. Vilar, J. Martínez, et al. (2010) Development of a framework for fire risk assessment using remote sensing and geographic information system technologies. Ecological Modelling 221:46-58.

Cohen, J.D. (2000) Preventing disaster: home ignitability in the wildland-urban interface. Journal of Forestry 98:15-21.

Cohen, J.D., B.W. Butler (1996) Modeling potential structure ignitions from flame radiation exposure with implications for wildland/urban interface fire management, Thirteenth Fire and Forest Meteorology Conference, Lorne, Australia.

Delfino, K., and C.A. Dicus (2007) Kennedy Meadows Community Wildfire Protection Plan. Available at http://www.krvfiresafecouncil.org/KennedyMeadowsCWPP.pdf $<01$ November 2008>

Dicus, C.A., and M.S. Scott (2006) Reduction of potential fire behavior in wildland-urban interface communities in southern California: a collaborative approach. P. 729-738 in Andrews, Patricia L.; Butler, Bret W., comps. Fuels Management-How to Measure Success: Conference Proceedings. 28-30 March 2006; Portland, OR. Proceedings RMRS-P-41. Fort Collins, CO: U.S. Department of Agriculture, Forest Service, Rocky Mountain Research Station.

District, R.S.F.F.P. (2004) Sheltering in Place During Wildfires: a Modern Approach to Living Safely in a Wildland-Urban Interface Community. Rancho Santa Fe, CA.

Dombeck, M.P., J.E. Williams, and C.A. Wood (2004) Wildfire policy on public lands: integrating scientific understanding with social concerns. Conservation Biology 18(4):893-889.

Greenberg, J.D., G.A. Bradley (1997) Analyzing the urban-wildland interface with GIS: two case studies. Journal of Forestry 95.

Jain, A., S.A. Ravan, R. Singh, K. Das, P. Roy (1996) Forest risk modeling using remote sensing and geographic information systems. Current Science 70:928-933.

Jaiswal, R.K., S. Mukherjee, K.D. Raju, R. Saxena (2002) Forest fire risk zone mapping from satellite imagery and GIS. International Journal of Applied Earth Observation and Geoinformation 4:1-10. DOI: http://dx.doi.org/10.1016/S0303-2434(02)00006-5 .

Menakis, J., J. Cohen, L. Bradshaw (2003) Mapping wildland fire risk to flammable structures for the conterminous United States, Proceedings of Fire Conference. pp. 41-49.

Murnane, R.J. (2006) Catastrophe risk models for wildfires in the wildland-urban interface: What insurers need. Natural Hazards Review 7:150-156. 
National Interagency Fire Center (2014) Historically significant wildland fires. Available at http://www.nifc.gov/fireInfo/fireInfo_stats_histSigFires.html <15-July-2014>

Nourbakhsh, I., R. Sargent, A. Wright, K. Cramer, B. McClendon, M. Jones (2006) Mapping disaster zones. Nature 439:787-788.

Ostergren, D.M., J. Abrams, and K. Lowe (2008) Fire in the forest: Public perceptions of ecological restoration in north-central Arizona. Ecological Restoration 26(1): 51-60.

Prestemon, J.P., J.M. Pye, D.T. Butry, T.P. Holmes, D.E. Mercer (2002) Understanding broadscale wildfire risks in a human-dominated landscape. Forest Science 48:685-693.

Quarles, S. L., Y. Valachovic, et al. (2010). "Home survival in wildfire-prone areas: building materials and design considerations." ANR Publication 8393.

Radeloff, V.C., R.B. Hammer, S.I. Stewart, J.S. Fried, S.S. Holcomb, J.F. McKeefry (2005) The Wildland Urban Interface in the United States. Ecological Applications 15:799-805. DOI: 10.1890/04-1413.

SanGIS (2014). Regional Data Warehouse, County of San Diego.

Stewart, S.I., V.C. Radeloff, R.B. Hammer, T.J. Hawbaker (2007) Defining the wildland-urban interface. Journal of Forestry 105:201-207.

Syphard. A.D., V.C. Radeloff, N.S. Keuler, R.S. Taylor, T.J. Hawbaker, S.I. Stewart, and M.K. Clayton (2008) Predicting spatial patterns of fire on a southern California landscape. International Journal of Wildland Fire 17:602-613.

Theobald, D.M., AND W.H. Romme (2007) Expansion of the US wildland- urban interface. Landsc. Urb. Plan. 83(4):340 -354. 